\title{
The development of the Norwegian Petroleum Innovation System: A historical overview
}

\author{
Ole Andreas H. Engen \\ University of Stavanger \\ Correspondence: ole.a.engen@uis.no
}

\begin{abstract}
This paper addresses the development of the Norwegian Petroleum Innovation System. The characteristics of the Norwegian Petroleum Innovation System were on the one hand the increasing ability to solve bottlenecks connected to production and operation on the Norwegian shelf, and on the other a gradual learning process which enabled a large portion of Norwegian participation in the petroleum business. While the initial phase of the petroleum development of Norway in the sixties was characterised by an absorptive capacity of receiving new technology, the building of Norwegian competence in the seventies and eighties was in certain respects directly shaped by public policy in order to participate. With the Condeep design it became possible to speak of an independent Norwegian petroleum industry. The development of Norwegian producer and supplier companies signified that petroleum activity in Norway was entering a new phase. In the R\&D System of Norway petroleum education and research were introduced at several levels. Due to new cost efficient technologies introduced in the nineties, we may say that the adjustment was concluded by the beginning of $21^{\text {st }}$ century. The Norwegian oil and gas actors perceived themselves ready to fully participate in the international system of energy producers.
\end{abstract}

Version of 06.08.2007

TIK Working paper on Innovation Studies No. 20070605

\footnotetext{
*This paper is part of the project "Innovation, Path-dependency and Policy" (IPP) carried out at the Centre for Technology, Innovation Culture (TIK), University of Oslo with the support of the Norwegian Research Council (Contract no. 154877). However, the Centre, University and Research Council are not responsible for the content of the paper, which is the sole responsibility of the author(s).
} 


\section{Introduction}

This paper addresses the development of the Norwegian Petroleum Innovation System. The foundation of a Norwegian Petroleum Innovation System was laid through the establishment of a particular organisation for offshore oil production that allowed Norwegian participants to convert domestic industrial competence bases into large areas of competencies for offshore oil production. The adaptation of the international oil industry into a Norwegian context was encouraged by a political strategy of integrating domestic firms and enterprises into the large development projects. International oil companies, a wide range of suppliers and local communities accepted this because it facilitated their exploitation of the Norwegian continental shelves, induced job creation, new industrial competence and regional and national development. The petroleum industry, which at the outset was largely foreigncontrolled, was thus transformed into a Norwegian Petroleum Innovation System through alliances within the Norwegian industrial environment, Norwegian oil companies, the R\&D sector, public administrative institutions and Norwegian politicians (Andersen 1993, Nelson 1993, Engen 2002). Moreover, through different historical phases the petroleum innovation system became more closely integrated into the Norwegian national innovation system and actually became a cornerstone of that system (Gulbrandsen \& Nerdrum 2007). In this paper we ask whether Norwegian politicians, the Norwegian administration and Norwegian industrialists contributed to the establishment of this particular industry, and how a domestic knowledge and competence base was created to enable the adaptation and integration of this particular industry. 


\section{Institutional conditions and absorptive capacity}

An initial assumption for adapting a new innovation system such as the petroleum industry is that during the course of inward technology transfer, sufficient competence in the application of the technology and organisations is acquired such that new personnel will be able to undertake new innovations and improvements. This is normally referred to as "absorptive capacity" (Cohen \& Levinthal 1990). Absorptive capacity refers to the participants' role in initiating a strategy for the selection and utilisation of technology. In the first phase it was the international companies which established the premises for transfer, but both public institutions and private actors in Norway negotiated in a manner that laid the foundations for "national absorptive capacities" upon which it was possible to build at a later stage in the development. The capacities comprised fragments of expertise which functioned in concert, fragments that together helped create national institutional systems for receiving and adapting a petroleum innovation system.

\section{Institutional capacity}

The first official specific Norwegian measures for institutional absorptive capacity comprised the granting of concessions - and taxation laws (Hanisch and Nerheim 1993). ${ }^{1}$ The concession laws became the primary control instrument for the state in determining which companies should be granted permission to operate in the Norwegian sector and where the operations were to be concentrated, namely which blocks were open for tender. These laws were legally binding for all implicated parties and thereby clarified the relationship between the petroleum sector and the Norwegian State. The laws guaranteed the companies' rights simultaneously with expressing the sovereignty of the state over the Norwegian area of the continental shelf. In fact, judicial sovereignty is the basic requirement for all economic activity. The market must comprise a set of rules defining the negotiating space of the actors including the legal 
aspects of ownership and contractual specifications (Hodgson 1988, North 1990). The concession laws and the taxation system in the Norwegian sector seen in this perspective comprise a regulation of economic activity, in this case the private exploitation of society's resources. These form parts of an agreement or contract between the state and the private company as to how the resources were to be exploited and the proceeds distributed.

In Norway, these types of "contracts" were not unfamiliar. The main principle was largely similar to the concession system formulated some fifty years previously in association with the development of electricity in Norway (Wicken 2007). In the development of both the electricity and petroleum innovation systems, the relationship to foreign capital was central. Foreign capital has always been regarded with scepticism, but has become recognised in varying degrees as necessary to the industrialisation process in Norway. Both at the turn of the century and in the 1960 's there was a desire to attract foreign capital to Norway. But this capital was to be controlled, to serve the interests of Norwegian society. In both the regulatory regimes mentioned, state policy created incentive for integrating new innovation systems in Norwegian society. The incentives were derived partly from the concession system itself which required that Norwegian subcontractors were to be employed, but were also associated with the authority granted to Norwegian government agencies to distribute rights among those companies and bodies that they considered would best take into consideration Norwegian interests.

Concessions as a form of regulation were the subject of internal Norwegian jurisdiction. Those concluding negotiations for concessions on the continental shelf were lawyers with a thorough knowledge of the legal and administrative process. It is reasonable to assume that previous practice in the electricity concessions influenced the procedures for oil and gas. At the same time the political approach in respect of foreign capital acquired legitimacy. Here the 
procedures were in the tradition of the Lie Commission. ${ }^{2}$ An organisational regime was, in other words, both politically and judicially legitimate. Both the aims and the means were available when the foreign companies presented themselves, and traditions existed enabling these means to be utilised (Wicken 2007).

In the meantime, it is important to point out that the formation of regulations in Norway was not a process where representatives of the Norwegian administration independently determined the outcome of the negotiations. During the course of the negotiations it was the oil companies who set the pace and proposed a system of licenses or concessions. In this regard the regulations were formulated according to the desires of the oil companies. But alternatives existed both for the Norwegian negotiators and the oil companies. In the first instance certain companies desired to obtain the sole rights to resources on the Norwegian continental shelf. This solution had been chosen by the Danes, giving AP Moeller sole rights on the Danish continental shelf, although this rapidly ceased to be of interest (Andersen 1993, Hahn Pedersen 1997). In such situations the authorities lose an essential part of their controlling functions, and risk losing a potential fortune.

\section{Industrial capacity}

During the first stage of establishment, it was the actors in the private sector that realised the possibilities for Norwegian industry. These comprised three groups: the engineering industries, shipping and the only national concern of international scale - Norsk Hydro. In the latter part of the 1960 's, shipbuilding experienced a boom period that lasted into the early 1970 's. At the same time the industry had undergone a long period of transformation in design and construction techniques that emphasized sectional construction, rather than building a complete unit from the keel up. In sectional construction, the separate sections are constructed independently and then finally welded together as a unit. This technique implied a more 
specialised production at each of the yards. Individual shipbuilders thus could develop specialized expertise connected with this form of construction, which in addition contributed to maintaining the geographically dispersed pattern of the industry. ${ }^{3}$ This form of production organisation also increased the need for reporting and administrative controls to monitor the individual parts of the process. In aggregate one may refer to a development of a joint competence within individual firms and the industry as a whole. This contributed to the emergence of new groups of shipbuilders who individually were able to execute specialist tasks and together could undertake complex construction operations such as building oil rigs and platforms.

When the international oil companies became established in the North Sea, parts of the Norwegian shipbuilding industry were prepared. As early as 1964 the Aker-group planned the establishment of three companies: one concerned with drilling, one associated with supply services, and a partnership company for the construction of oil platforms. The latter resulted in the construction of the drilling rig, Ocean Viking, where work was split among several yards with the main base in Nyland Vest. One important partner in the Viking project was Rosenberg Shipyard in Stavanger which enabled deliveries to take place as early as $1967 .{ }^{4}$ This early accord and the experience which the Aker Group acquired was important for subsequent platform-construction projects, notably the Aker $\mathrm{H}-3$ oil platform. The development of co-operation and partnership relationships opened up the possibility for accepting relatively large commissions and to utilise the expertise accrued by the local yards and engineering workshops (Hanisch \& Nerheim 1993).

The second group that became involved with the petroleum system in the early years of the sector's development comprised Norwegian shipowners. Generally, these operated under two different headings. The first covered those who were already familiar with the workings of the 
international oil industry--in $1965,20 \%$ of the world's tanker tonnage was registered in Norway. In spite of the fact that the oil companies themselves transported half of the crude oil from the Near East and North Africa, it was the independent shipping companies that transported most of the oil from the Persian Gulf. In other words, Norwegian shipowners were a part of the international petroleum system and understood the rules of the game. The second group represented Norwegian financial institutions with considerable interests in Norwegian shipyards and the shipbuilding industry, simultaneously having significant political influence at both the local and national levels.

The Norwegian international company, Norsk Hydro, played a role in petroleum exploitation in Norway from the beginning, initially relying on its international associations. At this time the company had a number of French shareholders, which proved important in connection with approaches from the French oil industry regarding participation in a project aimed at oil exploration and extraction in the Norwegian sector. Hydro's interest in French capital led to the formation of the Petronord group and for Hydro, oil became an increasingly central feature. As early as the mid1960's the initiative had been taken to build up an oil-technical staff internally, and a number of plans were formulated which had the aim of establishing an independent oil industry in Norway. Within an industrial complex such as this, it was expected that Norsk Hydro would play a central role. Many of the initiatives undertaken did not meet the favour of the Norwegian authorities. ${ }^{5}$ Neither at this time, nor later, was the company accorded a central role within Norwegian oil policy, in spite of widespread expectations that Norsk Hydro would fulfil this role. Instead, the Norwegian government decided to establish a new fully integrated state oil company, Statoil, relegating Norsk Hydro to a secondary role in the early years of the industry's development. 
In spite of not having a leading national position, Norsk Hydro's role in this early phase is relevant in our discussion. Throughout the whole of this century the company has played a significant role in the development of Norwegian industry, particularly in the electricity system, the chemical industry and aluminium (Moen 2007). Through its integrated activity, the company has been a central agent in the modernisation process. In the light of its prominent role in history, it was not unnatural, therefore, that to assume that Norsk Hydro would be an important actor in the Norwegian oil industry (Wicken 2007). As we have already indicated the company had positioned itself with this role in sight. Compared with the UK, Norway lacked strong actors with the ability to play an independent role in the oil system; Hydro was the single Norwegian firm capable of such a role in Norway's embryonic oil industry. Whether the company actually had this ability in the early phase has never been conclusively proved. But there was not sufficient political backing for Hydro's stance. In the later phases of the oil industry's development in Norway, however, Hydro became one of the important actors along side the state owned company, Statoil.

Norwegian industry thus included a number of firms that sought to establish a position in the field. New associations were made through channels of existing technology. Some actors attempted to establish themselves in such manner that this would be to the advantage of the industries already established and that the existing international network was utilised. Nevertheless, it is important to point out that in this phase there was no mention of an independent Norwegian investment in technology, and special competence had to be imported. The central issue was to establish appropriate connections where the Norwegians could participate and thereby gain profitable experiences.

These again are examples of what we may refer to as fragments of private absorptive capabilities. Within the partnership of shipping and engineering there existed experience that 
could readily be used when facing new concepts in technology, knowledge that enabled firms to utilise the new technology. But as earlier been pointed out, these contacts were also the result of existing technological experience within the industry as a whole.

\section{International Economic and Political Conditions}

Compared with oil production off the Texan coast or in the Middle East, the development projects in the North Sea were initially an expensive venture for the international oil companies. Nevertheless, there was no lack of will to invest. The individual companies manifested strong interest to carry out surveys on what became the British and Norwegian sectors. On a purely schematic level, we may speak of factors that induced the companies to search for new territory, and factors that increased the companies' expectations regarding new business activity with high economic returns.

In the years following the Second World War, the oil industry was dominated by seven companies: Exxon, Gulf, Standard Oil of California, Texaco, Mobil, BP and Shell (the Seven Sisters). In the global context these operated more or less as small, mobile states with considerable independence of and influence over national governments. Nevertheless, their significance became gradually reduced during the 1960's and 1970's. Whereas the market share of the so-called 'seven sisters' comprised $98.3 \%$ of the world total in 1950 , this had declined to $89.0 \%$ in 1957 , and further to $76.1 \%$ in 1969 . In the same period, the share of other smaller companies increased correspondingly from 1.8 to $23.9 \%$ (Engen 1997). The socalled "Majors" had thus lost ground to the independents. The explanation for this was largely to be found in the rapidly increasing demand for and consumption of energy in Europe and the USA. The Majors alone were not able to meet this demand and thereby created niches in the market for new and smaller companies. Another factor was the nationalisation ideology 
that had sprang up in the Arab world. The oil companies' host nations began to exert pressure on the oil companies, demanding higher payments for concessions, among other things. The Majors were generally not particularly interested in this form of re-negotiation. On the other hand, the independent companies were more willing to accept new economic conditions, and therefore were more easily able to obtain access to the new oil reservoirs.

In 1960, OPEC - The Organisation of Oil Exporting Countries - was established. The organisation was founded on the basis of the desire to increase national control over oil reserves. As suggested above, the situation was that a considerable part of the profits from oil production did not accrue to the benefit of the individual host countries but resulted in increased profits for the international oil companies. Simultaneously, many oil-producing nations became apprehensive about the risks of overproduction in the face of expanding reserves. The aim of OPEC was to encourage changes in the taxation systems, to introduce production quotas and to support measures for the nationalisation of concessions already granted. In the 1960 's, changes were largely limited to the taxation systems. But in the 1970 's, the organisation emerged as a significant influence on production and markets through its use of a broader range of devices. From March to October 1973, OPEC announced sharp production curbs and strong tax hikes for member countries, which brought about a quadrupling of the spot price for crude oil (Hanisch \& Nerheim 1993). The nominal price level for oil around 1970 was actually under \$2 per barrel. At the beginning of 1973 the price had risen to $\$ 11.50$ per barrel. The rise continued from 1975 to a level of about $\$ 15$ in $1978 / 79$, and then jumped to $\$ 38$ in 1980 . In real terms this is approximately the same price level as that of 2007.

The 1960's signified, in other words, the start of a process that threatened the dominance of the international companies in parts of the world that they had hitherto considered as their sole 
domain. The international political climate was of decisive significance for the companies' investment programs. Both the independent and the major companies in this period were on the lookout for regions that satisfied their demands for political stability, and the North Sea emerged as one of great promise. When the region was opened for oil exploration, it was not particularly remarkable that the oil companies emphasised the significance of establishing a framework that would regulate production and guarantee a certain security for their investments.

The new and changed conditions facing the international oil companies in the 1960's in the form of more stringent demands by the oil producing nations, together with the increased level of political turbulence, functioned as a "push-factor" for the oil companies in the direction of the North Sea. The finds in Groningen (Netherland), the possibilities for locating closer to the energy markets, plus the fact that the area was characterised by permanent political stability, were clear "pull factors". These factors influenced the negotiating desire of the companies and strengthened the bargaining position of the Norwegian government and Norwegian firms in the early development of the oil industry.

\section{National Institutional Responses}

The economic and political foundations of Norway's oil industry were created in the seventies with the establishment of Statoil, the Norwegian Petroleum Directorate (NPD) and the Ministry of Oil and Energy (MOE). Simultaneously, the state put a brake on new licenses. The latter step was directly connected with public officials' wish to have time to build up Norwegian competence. When the fourth concession round was introduced in 1978, it coincided favourably with a doubling of the oil price and gave additional impetus both for oil companies and public officials to unite on common goals regarding competence development 
and choices of technology (Hanisch \& Nerheim 1993). As we shall see later, it was at this time that the technical trajectory characterised by large integrated platform constructions manifested itself on the Norwegian shelf.

From its establishment, Statoil became the main instrument developing Norwegian petroleum competence and shaping a particular technical and organisational trajectory, relying on the concession system to strengthen its dominance. ${ }^{6}$ Agreements regarding education and transferring knowledge and technology from other companies were negotiated, and Statoil itself took the role of intermediary in delegating tasks to Norwegian industry. Industrially, the company contributed greatly to technical and organisational adaptation by utilising traditional industrial networks and functioning as an agent transferring and adapting international petroleum techniques and competence (Engeland 1997).

The outlook for long-term production and positive cash flow also induced the international oil companies to be flexible in meeting the demands of public officials regarding their working plans, choice of suppliers, and measures to transfer competence to Norwegian companies and research institutes. ${ }^{7}$ This form of governmental organising for a national petroleum industry is fully compatible with what Michael Porter (1985) denotes as "infant industry policy", and it has been convincingly demonstrated that such a policy contributed to the creation of a petroleum industry cluster in Norway. ${ }^{8}$ The international oil companies on their side accepted the terms as legitimate because the expected income was large. Representatives of the Norwegian government considered these terms as absolutely necessary for securing the greatest possible share of oil profits for the Norwegian society.

During the same period, the UK built up a similar regulatory framework as Norway for the exploitation of its North Sea reserves. The UK government initially implemented a petroleum 
tax system and a system of handing out licences, and established certain institutional bodies in order to handle petroleum cases. Developments in the UK domestic oil industry soon followed a different path from that of Norway. Although both Norway and the UK manifested state activism towards the oil industry until the late seventies, only the Norwegians further developed "an infant industry policy" during the eighties characterised by a sophisticated institutional framework. By contrast, the UK chose to deregulate and deemphasise active governmental participation. In general, we may say that UK oil policy in the eighties consisted of little more than a passive concession practise that relied on a tax policy that was compatible with the objectives of the Thatcher government (Andersen 1993).

As the Norwegian oil companies and main suppliers gradually built up their competence in the shelter of a protectionist policy, an institutional maturation process took place in the public administrative apparatus. The development of the Norwegian Petroleum Directorate (NPD), established in 1973, shows how the role changed in accordance with the evolution of Norwegian industrial competence. The formation of NPD followed traditional administrative practice (Olsen 1989), but the Directorate engaged personnel with little experience in the petroleum industry. This often resulted in the literal, rigid application of regulations in order to reduce its own insecurity. In some circumstances, public control and surveillance contributed to "over-sizing" the individual offshore platform installations and project organisations. This rigidity subsequently changed, as NPD built up independent competence to handle complicated technical problems and complex development projects. 


\section{The development and integration of the Petroleum Innovation}

\section{System}

Would the technical and organisational development and the associated competence creation in the Norwegian oil industry have taken another direction if the political and economical conditions had been otherwise? The answer is probably yes, but it is highly uncertain what would have happened and which concepts and competence bases would have come into being. In any case, given the situation in the international petroleum market at that time, the international companies chose not to take a very tough position in negotiating with Norwegian officials. The international companies accepted the fact that the Norwegian portion was growing and that Statoil had achieved independent competence sufficient to eventually dominate the industry. They also accepted directives from the Norwegian administration on how regulations were to be implemented, even though these directives restricted technological choices. The petroleum industry in Norway thus became politicised, reflecting the the government's commercial interests and its aggressive "infant industry" policy.

\section{[FIGURE 1 ABOUT HERE]}

Figure 1 and figure 2 show the impact of the petroleum sector on the Norwegian economy in a historical perspective, focusing on the growth in the share of GNP and the total employment accounted for by the industry from the early 1970 s through the early $21^{\text {st }}$ century. From the beginning of the seventies until 1985, output and employment grew rapidly. Subsequently, the sector has experienced periods of instability - both after 1986 and in the late nineties. Every period of decline is associated with price drops on the international petroleum that induce declines in domestic investment in the sector rate. Both figure 1 and figure 2 show the 
historical significance of the Norwegian Petroleum Innovation System but also illustrate the sector's instability, which in turn has affected growth and employment in the overall Norwegian economy.

\section{[FIGURE 2 ABOUT HERE]}

Nevertheless, in spite of these economic fluctuations, the industry has over a period of 40 years experienced major organisational and technological changes and has shown a remarkable capacity in adoption and innovation to handle changing environments. From its beginnings in the 1960 s up to 2007 , the offshore petroleum industry has passed through several transition periods regarding economic conditions, regulatory framework and organisational/technological development. It is useful account to divide this evolutionary process into five phases.

The first two phases, "Entrepreneurial" and "First Consolidation," describe the establishment of the innovation system and the shaping of a particular Norwegian way of organising it. This period witnessed the development of a regulatory regime and the establishment of Statoil and NPD. Moreover, it included an active infant industry policy and the emergence of Aker and Kvearner as main suppliers. The third phase, "Maturation," denotes the transition phase in which the innovation system was exposed to less favourable economic conditions. Nevertheless, the phase was characterised by a improvements in the capabilities of the Norwegian R\&D system, increased public spending and larger involvement in petroleumrelated research within the Norwegian universities. Finally, the last two phases, "Reorganisation" and "Second consolidation," describe the erosion of the infant industry policy and the rebuilding of an innovation system that is better adapted to international 
competitive requirements and liberalised energy markets. This latest development resulted in part from the NORSOK programme, a co-operative project between the Norwegian government, the oil companies and the supplier industry that sought to reduce the average cost of exploration and production on the Norwegian shelf by approximately 50 percent. In the next section we will go thoroughly into the five phases and analyse how particular characteristics of the innovation system have materialised in technological choices on the Norwegian continental shelves.

\section{Entrepreneurial phase 1970-1976}

The main characteristic of the entrepreneurial phase is that the international oil companies or the Norwegians did not know what oil development in the North Sea implied. Phillips brought with them technological experiences from other regions e.g onshore drilling in the Middle East and offshore experiences in the Gulf of Mexico. Norwegian policymakers were unsure how the regulatory regime (Consession system, Tax System) would work in practice when the field discovered started to produce.

The development of the petroleum fields "Ekofisk" and "Frigg" in the 1970s thus became important arenas for "learning by doing" for the international oil companies, the Norwegian authorities and Norwegian industry (Olsen \& Engen, 1997). While the international oil companies preferred light platform designs and sub-sea solutions with little involvement from Norwegian subcontractors, the authorities insisted on a design that implied as high participation from the Norwegian industry as possible. The Ekofisk- and Frigg-fields represented a breakthrough for Norwegian contractors due to the introduction of concrete technology for offshore platforms that was well known in Norway and relatively easy to 
adapt to the oil industry. They were key projects in the transfer and development of new platform technology of Norway.

Nevertheless, Ekofisk was an expensive project with large cost overruns during the seventies. But the high price of petroleum provided very good financial results in spite of $100 \%$ cost increases for individual parts of the project, and the favourable techno-economic conditions allowed Phillips to accept the "Norwegianisation" policy. In spite of a sceptical attitude towards the Norwegian government, the company adjusted to the regulations, as was demonstrated by the company's building of a huge storage tank on Ekofisk. It was the Norwegian contractor firm Høyer Ellefsen that suggested the building of the concrete tank. From Phillips' point of view it appeared clearly advantageous to engage a Norwegian firm for the construction job, not least on political grounds. Institutionally speaking, the storage tank illustrates how the incentives stemming from the concession system functioned. The storage tank was built in Norway and involved Norwegian suppliers and engineering competence belonging to the hydroelectric power system of Norway (water power plants and dams). For Phillips, building the storage tank gave the company credit when it came to new applications for extending the Ekofisk area (see figure 3 and textbox 1). In this negotiation round, there was also great willingness to come to an agreement because of the enormous income potential. In spite of some reservations, Ekofisk must be considered the first development in which the contour of a Norwegian petroleum innovation system is visible.

[FIGURE 3 ABOUT HERE]

[BOX 1 ABOUT HERE] 
The Frigg field was developed with a total of seven anchored platforms, three of concrete and four of steel. The total cost was NOK 26 billion (1997). When the field was declared commercially viable in April 1972, no stipulations were laid down by the Norwegian government with regard to technological matters nor to the way in which the gas would be transported to land. Frigg was at that time the world's largest offshore gas field and the production started in 1977. As with Ekofisk, there was a great cost explosion, but nevertheless the Frigg field was considered profitable from the start. The economic risk associated with meeting the design and technology requirements of the Norwegian government was therefore judged by the foreign oil firms to be small. All internal concept studies showed that economically the project was sound and after the quadrupling of the prices in 1973 all doubts about financial prospects disappeared.

Expectations among Norwegian officials for the Frigg field were also high, not least because of an increased Norwegian share in the field. A 50/50 division of anchored steel and concrete construction suited Norwegian officials. The Norwegian portion of the supply business gradually increased during the development phase of the field. For Ekofisk in 1973 this portion was 20\%, whereas for Frigg it was 28\% in 1974 (Engen \& Olsen 1997). In this phase however it was the international oil companies that dominated. As mentioned earlier, certain key actors among the Norwegian supplier industry were oriented themselves towards the international oil industry, but we can not speak of a "Norwegian Innovation Petroleum system" yet - not least because no Norwegian R\&D was involved and research institutes and Universities were almost absent from "the petroleum scene". 


\section{Consolidation 1977 -1980}

It was the development of the Condeep platforms on the Norwegian shelf that seriously introduced the Norwegians into the petroleum innovation system. The Condeeps were large gravity platforms placed on the sea bed, and the construction of these production systems were organised by the use of numerous Norwegian sub-contractors - among them Norwegian Contractors (NC) which was developed and owned by Aker. To manage the complicated setup, oil companies, suppliers, sub-contractors and authorities had to build up huge bureaucracies in order to control each other. This extremely bureaucratic way of organising the workplace was to some extent unknown in Norway, although it had long been characteristic of the international oil companies' operations, in order to protect themselves against opportunistic behaviour by close monitoring of contractors and a willingness to meet a former client in the court. The production costs became extremely high. The influential Norwegian stakeholders in the oil industry expanded to include politicians, governmental institutions, oil companies, suppliers and labour unions. They constituted complex networks of interests and objectives in which this phase of the innovation system was further shaped.

\section{[FIGURE 4 ABOUT HERE]}

\section{[BOX 2 ABOUT HERE]}

There are three integrated platforms with independent processing works on each field at Statfjord, the major project undertaken during 1977-1980. It was here that the development of Statoil's competence was built up sufficiently to enable the company to be capable of being an independent operator. For Statoil it was important that their modest competence gained from large offshore production plants could be utilised to the fullest. At that time, Statoil's only experience was with this type of platform, and Statoil and Mobil together constituted an absolute majority in the licensee committee. ${ }^{9}$ During the construction of Statfjord, the 
working partners were subjected to more substantial demands from Norwegian authorities. ${ }^{10}$ Political decisions and interpretations of regulations guided technological choices to a larger extent than before. From an extreme viewpoint we may say that public officials began to behave like technology shapers.

The large development projects of this period required new types of organising than traditional industrial projects in Norway. Accordingly, during the seventies, the transformation of the traditional shipyards into offshore suppliers was seriously implemented (Olsen \& Engen 1997, With Andersen 1986). Large engineering firms were engaged to work out designs and detailed specifications. These firms often got the job of surveillance and control of the very same construction work. Manufacturing firms were given the task of producing according to ready-made drawings - whether they worked or not. Operators built up their own shadow organisations that in turn monitored the engineering and manufacturing firms. In this way, every firm had its own clearly delineated and overlapping areas of work and responsibility. But in order to secure interfaces with the production process and to have legal protection in case of potential errors, enormous organisations and extensive bureaucratic procedures had to be established.

Engineering companies had an important position in the design and construction phase. On the strength of an initiative by the Norwegian company Aker, NPC (Norwegian Petroleum Consultants) was founded in 1973 for the purpose of securing national engineering control of Statfjord A (Engeland 1997). The Norwegian main suppliers Aker and Kværner had also built up equivalent departments. This required the recruitment of many more engineers than were available at the time. When all operators were required to choose Norwegians, a costly bottleneck developed in the industrial system, producing considerable wage increases for Norwegian engineering staff on these projects. 
Hence, efficient organisational models were not achieved. While the intention was a rational and efficient management system the outcome was, as mentioned above, a cumbersome, bureaucratic, labour-intensive management model. Norwegian participation thus had economic consequences. It was costly to develop new technical concepts and transfer competence to Statoil, and costly to train the Norwegians. Nevertheless, this developing innovation system generated national income and jobs, laying the foundation for a Norwegian petroleum industry. In this phase the Norwegian actors were gradually included in the petroleum innovation system through active infant industry policies. Statoil began its transformation into an integrated petroleum company and Aker and Kvaerner established themselves as main suppliers. That implied among other things that the main suppliers increase their emphasis on internal sources of innovation, developing and improving their technical and engineering solutions. Nevertheless, there was little scientific or technological support from public sources. The Norwegian Universities and R\&D institutions remained absent from the petroleum scene.

\section{Maturation 1981-1988}

The development and commissioning of two big oil-fields (Statfjord and Gullfaks) by Norwegian actors during the 1980s strengthened the organisational and technological networks linking national actors, who specialised in the only exploitation technology they knew at that stage (integrated gravity platforms). Strong political interventions gave priority to uniform and continuous investments in projects where Norwegian actors had acquired a compatible competence. Gradually, Norwegian actors acquired "know-why" competence within most sub-systems, making it easier to design procedures for safer operations. 
In 1979 the Norwegian government took a critical step towards domestic research capacity building through the establishment of the "good will agreements". Under these agreements, the international petroleum companies were given so-called "good will points" by contracting with Norwegian firms and research institutes for oil and gas related research and by developing Norwegian research institutions. The policy was characterised by a wellarticulated system of evaluating operator contributions to domestic capacity building. Financial support for R\&D was rewarded and transfer of know-how along with financial support was rated even more highly. Finally, the companies' overall contributions were reflected in their standing in the next concession round. For operators on the Norwegian shelf, the tax system also promoted R\&D spending by classifying R\&D-related costs as immediately deductible. The tax rate had in 1975 increased to $78 \%$ which in general implied that the State covered $78 \%$ of the costs. In sum, these regulations gave the institutional research sector in Norway a significant boost. Sintef (Trondheim), Christian Michelsens Research (Bergen) and Rogaland Research (Stavanger) were established in a very short time as major public R\&D contributors in the petroleum innovation system. Applied geology, well drilling technology and principles for enhanced and improved oil recovery became the main research areas for all these institutions (Gulbrandsen \& Nerdrum 2007).

The profitability of Statoil was dramatically improved by the oil price rise in 1980, and the accelerated tempo of development and costs thus continued. Accordingly, Statfjord C became an approximate copy of Statfjord B with an equivalent production capacity. Production began in 1985. Cost control for Statfjord C was very successful however, compared with the two previous platforms. ${ }^{11}$ As early as 1983 the operator could report that total costs had been reduced by approximately NOK 600 million and this, along with the high oil price, provided a very favourable profit picture for Statoil for the rest of the eighties. ${ }^{12}$ 
The Norwegian technical and organisational experiences on Statfjord were further utilised on Gullfaks, and the platforms are clear examples of the monumental technical concepts characterising Norwegian development projects offshore. But even more important, this was the first development on the Norwegian continental shelf in which all interests, both the operator and the main suppliers, were Norwegian. Statoil is the operator, receiving $85 \%$ of the output, with the remainder being divided between Hydro and Saga. The first construction consisted of two integrated platforms, Gullfaks A and Gullfaks B. Cost overruns did not develop on Gullfaks in the way they did on Ekofisk, Frigg or Statfjord, and it was therefore not necessary to adjust the budget upwards for either Gullfaks A or B.

The decision to develop phase I of Gullfaks, however, was not received with enthusiasm by the internationals. A sceptical attitude had been expressed by the Norwegian Conservative party (Høyre) about the role Statoil had begun to play in Norwegian oil policy (Rommetvedt 1991), which resulted in Statoil being deprived of some control of the income flow from the shelf. ${ }^{13}$ Nevertheless, the Norwegian industry on its part still saw the possibility for more contracts. The positive financial development of Gullfaks led to a second phase of development. Statoil exerted significant pressure on the Parliament to hasten the completion of the field, and it was confirmed later that the decision to do so was largely the result of the company's effective marshalling of arguments concerning employment and regional policy (Thomsen 1991).

Another important explanation for the pressure to speed up the development of Gullfaks C was the delay in the construction of the Sleipner field. The main reason for the delay was that Britain refused to enter into an agreement in 1985 of buying gas from the Sleipner field. According to plans, investing in Sleipner should have begun some time in the mid-eighties. ${ }^{14}$ Without some new development project, the delay of Sleipner could have caused a temporary 
downturn in the Norwegian suppliers' portfolios, something neither Norwegian politicians nor the supply industry wanted. It was therefore important to fill the vacuum.

Gullfaks $\mathrm{C}$ revealed a strong connection between public officials and operators, as well as showing how local and national industry and employment interests dominated the petroleum industry at that time. In retrospect, Gullfaks $\mathrm{C}$ appeared to be a purely political project in which considerations of employment onshore dominated concerns about technical and economic factors offshore. The development of Gullfaks $\mathrm{C}$ was also in line with the new petroleum policy which was adopted in 1983. Previously, a production ceiling limited output to 90 billion oil ton-equivalents. But by 1985 , the focus of policy had shifted to ensuring a stable pace of production investment, so as to stabilize the market for Norwegian suppliers. ${ }^{15}$ The foundation for Norwegian competence based on local participants was established. Now it was a matter of reaping profits from the developments and further increasing Norwegian participation.

With the development of Oseberg North, Norsk Hydro at last emerged as a dominant oil company in Norway along with Statoil. The state's good will towards Hydro started with the allotment of the blocks that would later become the Gullfaks field. ${ }^{16}$ The company had as mentioned in the sixties and seventies previously felt itself unfairly treated in the awarding of concessions and public officials' unwillingness to consider it as an integrating competent petroleum company (Ryggvik 2000).

The Oseberg field was discovered as early as 1979 and developed in two phases. Oseberg A has both a processing works and living quarters, and is built with a concrete undercarriage, while Oseberg B is a drilling and water-injection installation with a steel undercarriage. Phase 2 consisted of developing the northern part of the field, where Oseberg $\mathrm{C}$ is a satellite with an 
integrated production-drilling platform with living quarters, all constructed in steel. Oseberg has been characterised as a cheaper development project with better and more cost-effective technology than Statfjord or Gullfaks (Kristiansen 1997).

Oseberg however may be considered as a continuation of the "Condeep design", this time with Hydro as operator, drawing on the company's experience acquired by participating with Statoil at Gullfaks. They used the same concepts and organisation model, but it is important to emphasise that the company further developed techniques through incremental innovations that contributed to lower unit prices and more efficient operation and production.

In smaller fields that were discovered and developed before 1986, we find other technological concepts, but political influence is strong here as well, and is augmented by steadily stronger elements of Norwegian participation. In general, the technical concepts and organisational models can be seen as the result of the desire for Norwegian participation in the international petroleum industrial complex. Even though this served as an important basis for developing independent Norwegian competence, it required, as we shall show later, an external commercial shock to bring about a genuine transformation in Norwegian competencies to make the domestic industry internationally competitive.

During this phase we see a consolidation of the integrated production units, Condeep. The effects of the protectionist policy and the concession system that favoured Norwegian companies also became apparent during this period. The Norwegian main suppliers and their sub-contractors which now together with Statoil and Hydro and the smaller Norwegian Oil company, Saga Petroleum, increased their dominance on the Norwegian shelf. The cooperation system that stemmed from the sixties was further developed. In order to handle the large development projects, the Norwegian suppliers co-operated rather that competed and the 
large projects were to a large degree monitored and governed by the oil companies. Finally, the technology agreements and increased public funding of petroleum research (see figure 5) linked the Norwegian research system, including the research institutes, to the petroleum innovation system. For all of these reasons, we denote this phase as the "maturation" of the Norwegian Petroleum Innovation System.

\section{Reorganisation 1989-1996}

From 1981 to 1985 the petroleum price stabilised, but sank in real terms. In 1986 Norwegians experienced a shock for the first time, with the oil price bottoming out at $\$ 9$ per barrel. From 1987 to the mid-nineties, the price varied nominally within a range of $\$ 17$ to $\$ 25$ per barrel (Engen \& Olsen 1997). The 1995-2005 period was also characterised by fluctuations, but in general - if we include the last three years- prices have climbed steadily.

The decline in the oil price from 40 to 9 dollars per barrel (1986) imposed a shock to the whole innovation system. It unveiled its vulnerability and the lack of national technological alternatives (Olsen \& Sejersted, 1997, Engen, 2002). The main actors within the Norwegian petroleum innovation system were strongly encouraged to co-operate in order to develop new cost-saving technologies by forming NORSOK (abbreviation for Norsk Sokkels Konkurranseposisjon), an industrial program for technological development and new standards, organisational development and new contractual relations, regulations, and new initiatives for co-operation and negotiations between oil companies and their suppliers. The main objective was to reduce average costs by as much as $50 \%$. The program was inspired by the similar initiative taken by the British, CRINE (Cost Reductions in a New Era). NORSOK induced a process that gave the actors greater freedom in planning and implementing 
alternative technological solutions. Ambitious overall goals for increased efficiencies, standardization and reduced costs were introduced.

During the eighties, the development paths of the Norwegian and British continental shelf diverged. The Norwegian Innovation Petroleum System was integrated into the Norwegian economy by institutional arrangements such as the Goodwill agreements, and the great development projects (Statfjord and Gullfaks) were also governmental instruments reducing unemployment and building up competence in the regions of Norway. In the UK, the Grampian region and Aberdeen experienced some of the same development as Stavanger in Norway (Gjelsvik et al. 2006), but the North Sea oil and gas industry accounted for a much smaller share of total UK employment (about 100000 in general employed in the eighties) and GNP than was true of Norway. The average size of the field was smaller and required other concepts that were cheaper and more standardized than the Condeep technology.

Accordingly, the companies on the UK shelf experienced more cost-efficient development and production. When the Norwegians faced the fact that the old "technological regime" had to undergo a cost-efficient "makeover", it was natural to look to Britain and try to establish similar institutional arrangements as CRINE. To a certain extent, NORSOK represented an institutional break with the protectionist praxis of the concession system and the technology policy of the goodwill agreements. NORSOK was a collaborative project among the government, oil companies and the main suppliers to replace the old technological regime with new, more cost-efficient routines and procedures. This implied a political shift from an active and interventionist oil policy to a more passive one that sought to link various actors rather than dictating terms to them. In practice this meant that both oil companies and main 
suppliers enjoyed greater freedom when choosing technological concepts, subsuppliers, location of bases, headquarters etc.

During this phase the R\&D institutions in Norway that were connected to the petroleum innovation system increased their role in a period of financial recession. R\&D funding grew rapidly throughout the 1980's and came to account for a significant fraction of the industrially oriented R\&D. During the late 1990's, oil and gas companies alone funded 12\% of Norway's total R\&D expenditure. The government also took a more direct role for industrial R\&D as a whole. From 1990 the Norwegian Research Council was assigned important tasks concerning technological development offshore. The public research programs in oil and gas in this phase included one program that had great importance in developing efficient technologies for the Norwegian Shelf. The Ruth research program (Reservoir Utilisation through advanced Technologial Help) was initiated in 1991 as a collaboration among the Norwegian Research Council, the NDP and several oil companies and research institutions. The program produced significant results in a short time period, attracting industry attention and new business participants. The two most important technologies that came out of Ruth were gas injection and combined water and gas technologies, whereby water and gas are pumped into the reservoir to improve recovery. When the program came to an end the average planned oil recovery rate from existing fields had increased from 34 to $41 \%$. These results made it possible to utilize existing technologies more efficiently for field development and made smaller and marginal fields more attractive to develop.

\section{[FIGURE 5 ABOUT HERE]}

Figure 5 shows the fluctuations in public spending in oil and gas exploration and production, illustrating an interesting pattern. After the price drop in 1986, public R\&D almost doubled 
until 1988. Then it fell the following two years and recovered during the planning phase of the NORSOK programme. However, during the implementation of the NORSOK programme 1995-1998, R\&D policy was characterised by a lack of coordination, and the decline in output and employment in 1998/99 (See figure $1 \&$ 2) produced an increase in R\&D expenditure.

The evolution of the new technical concepts employed in Norway's emergent oil and gas industry also reflect the operation of complex economic and political influences. The complex platform constructions (Condeep) dominated production activity and were accompanied by large bureaucratic organisations. The dominance of Condeep reflected the fact that this particular technology had generated its own momentum in the eighties. Thirty to forty thousand jobs were connected to the concept, Norwegian suppliers had learned to do things in that particular way rather than developing more general construction competences, and the Condeep design satisfied the desire of the Norwegian government to secure a high level of employment. Its dominance indicates the integration between the international and the Norwegian petroleum system, around a production design and competence base that has developed so that it satisfies political, social, and technical criteria simultaneously - criteria that all participants understand and accept.

It no longer appears to make a difference for the technological choices within the petroleum innovation system whether the operators on the field are Norwegian or foreign. Large integrated platforms such as Troll and Draugen were built by Shell, while both Statoil and Hydro are involved in developments in which subsea installations are used (See figure 6). Meanwhile, the proportion of Norwegian concessions rises. To some extent we may say that the similarity in domestic and foreign firms' technological choices was one effect of the Goodwill agreements. Shell was one of the first international oil companies to utilise the Goodwill agreements effectively, e.g., by building the Ullrigg Well Center together with RF- 
Rogaland research in Stavanger. The center became one of the most important test facilities in Norway. The Godwill agreements linked Shell closely with the Norwegian oil industry and influenced the firm's acceptance of Norwegian technology policy and practice.

Technological choices for the Troll development were thus based partly on the infrastructure that had been built, but independent integrated installations were chosen for individual fields. Hydro had the responsibility for the construction of phases II and III of the Troll development and for the gas injection on Troll-Oseberg, exploiting results from the Ruth program. Troll was proven viable in 1979, and the field itself covered several blocks. Statoil holds the main rights to Troll with about $75 \%$ of the total; Shell and Hydro account for $8 \%$ and $7 \%$ respectively of the field's output.

The Troll project was seen in petroleum circles as a technologically advanced one, since it utilized new technology for monitoring and controlling the seabed via computers. The organisation of planning and construction however, did not break with established routines. Troll's construction showed again that the Condeep design was durable. In spite of the fact that the installations were scaled down several times as a result of changed conditions, one of the installations on Troll is the world's largest platform offshore.

Relatively soon after the price drop in 1986, it became possible to use designs that had not been considered earlier. On the Troll project and fields development afterwards new innovations in drilling and exploitation were implemented. This demonstrates two things: firstly, knowledge of and competence for alternative construction concepts had already been developed before the price drop in Norwegian as well as foreign companies. Secondly, one of the most important immediate effects of the price fall was not a change in companies' organisation of development projects, but political and public administrative acceptance of 
simpler designs (Olsen \& Engen 1997). Thirdly, the effects of increased R\&D begin to materialise in the improved feasibility of new designs.

Few fields were discovered and developed in the period between 1986 and 1995. Indeed, development of numerous fields was considered and rejected during this period. In 1986-96, between 50 and 60 fields were tested in the North Sea (and a total of about 120 on the Norwegian shelf) and assessed to have little or no profit potential. The reason for lack of interest on the part of the oil companies in developing these fields was that they were on the whole small, located far from existing infrastructure, and/or contained mainly gas. Even with new concepts, the high costs of development under the established organisation of work prevented exploitation of these fields. The underlying mismatch between the Norwegian way of developing a field and the profitability of oil production thus became a pressing problem for public officials, companies, and suppliers early in the nineties. Seemingly the technical trajectories, the Norwegian competence, the organisational procedures and finally the cooperative practice between the government and the oil companies had to undergo a transformation to become offensive and internationally competitive.

The new economic realities enforced new technological and organisational solutions on the Norwegian shelf. The NORSOK - co-operation and increased R\&D expenditure stimulated new organizational and technological approaches to oilfield development. Moreover, during this phase Norwegian actors began to dominate most segments of the petroleum innovation system and we actually can speak of a Norwegian Petroleum Innovation system. Most applied technical research during this period was performed by the Norwegian research institutes and Universities, and the Norwegian Research Council became a major funder of R\&D in the petroleum industry. Nevertheless, oil companies - particularly the Norwegian firms - still clung to old search procedures and well known principles. Planning and development were 
organised according to patterns from the seventies and the eighties. Compared to the British offshore oil sector or fields developed in the Gulf of Mexico, the time from discovery to production is almost three times longer in Norway. These long development cycles, among other factors, make development costs far higher in Norway's oilfields than in comparable developments elsewhere in the world. Despite new technical concepts and increased competence among all actors, the Norwegian oil system still did not possess sufficient competitive capabilities to place it among the international elite of the energy producers. At the beginning of the nineties these inefficiencies were seen by policymakers and managers in Norway's oil industry as serious problems that threatened the entire Norwegian economy.

\section{Second consolidation 1997-?}

During the second half of the nineties economic insecurity entered the Norwegian oil industry. The largest fields had been discovered and developed, or their final development was planned in the near future. Oil prices seemed to have stabilised at a lower level, and resource growth had gradually flattened out. The problem however, was not a lack of new discoveries, but rather that the new discoveries were considerably smaller and less accessible than previous fields. In addition, the discoveries contained more natural gas than oil. Nevertheless the investment rate continued to rise as a result of previously planned developments in the Sleipner, Troll, and parts of Oseberg sectors.

Two conditions nonetheless provided grounds for optimism. First, new technologies and simpler construction methods were deployed, and operating cost reductions in the neighbourhood of $30 \%$ were realised. The deployment of these new techniques required political acceptance of rationalisation and job cuts in the operating organisations. Both public officials and labour unions accepted the necessity of such measures in order to maintain 
profitability. The other condition was that the Norwegian Sea was opened as a petroleum province.

The challenges of new discoveries meant that public funding of petroleum research has been maintained at an even higher level than before during this period. During the late 1990's, two important programs were launched: The applied R\&D-programmes "Demo 2000" and "Offshore 2010". In both programs, suppliers and SME's are responsible for a larger part of the expenditure than previously was the case. The main funding for both programs, however, still comes from the Nowegian Research Council and the oil companies. The main objects of Offshore 2010 are subsea production, drilling technologies and well/fluid transportation technologies. DEMO 2000 seeks to develop new oil and gas fields through technology, improved execution within project budgets and new industrial products for new markets. In 2001 for the first time, the private share of R\&D expenditures in Norway's oil and gas industry exceeded the public share. The publicly funded programs appear to have catalyzed additional private $\mathrm{R} \& \mathrm{D}$ investment in this sector, in accordance with the NORSOK objectives: The petroleum research programs in this phase illustrate the still existing collaborative efforts in the Norwegian Petroleum innovation system and how the public R\&D infrastructure of Norway is closely connected to the petroleum sector and participates in solving technological challenges.

During the year 2000, floating installations, production vessels and subsea solutions were installed in the Njord, Norne Varg, Visund and Åsgard fields. New organisational models were employed and the main suppliers Aker, Kvaerner and UMOE accomplished extensive inter-organisational readjustments. Higher oil prices sparked an unpredented boom in the petroleum industry during this period, and in 1999 the number of employees exceeded 90000 . 
The terrifying scenarios developed only a few years earlier thus seemed to become irrelevant (See figure 2).

New inter-organisational models accompanied the new technological regime. The old contractual system based on dividing contracts among many suppliers was adapted to the Condeep design. The new and flexible technical concepts required simplified organisational models. Splitting up the contracts when the core expertise was gathered in one organisation was no longer rational. This process was one of the main effects of the NORSOK programme, which ended in 2001. Other characteristics of the new technological regime on the Norwegian continental shelves manifested themselves in greater use of unmanned installations and computer based technical solutions that require the further development of subsea technology and drilling techniques.

[FIGURE 6 ABOUT HERE]

[BOX 3 ABOUT HERE]

A more general organisational effect of these development trends was the industrial consolidation during this phase. First Statoil and Hydro consolidated their role by dividing the smaller Norwegian Oil Company Saga between them. Two large oil fields, Snorre and Tordis thus became part of the portfolio of the largest Norwegian oil companies. Together Statoil and Hydro achieved total control of the Shelf. Similar processes took place by the main supplier. The amalgamation of Aker and Kvaerner in 2001 meant that only one Norwegian supplier remained that could handle large petroleum contracts. The Norwegian Petroleum Innovation System had become dominated by a small number of powerful Norwegian actors. In historical perspective this is interesting. One the one hand we may say that this is the result of the different industrial strategies applied in the Norwegian oil industry in order to make the oil 
companies more competitive and to increase the technological capacities of the suppliers. On the other hand, this is a general trend that reflects the closer integration of the Norwegian Petroleum Industry - both suppliers and oil companies - with the international energy system.

By the end of 2002, these opposing trends within the Norwegian Petroleum Innovation System were still visible. On the one hand, controversies remained between the oil companies and the main suppliers about risk sharing within new development projects. These tensions reflected the fact that the main suppliers within the new contractual model had the main responsibilities throughout the entire construction process. Moreover, the greater responsibilities of suppliers for R\&D produced new questions about the ownership of intellectual property and patents resulting from their activities. Economic optimism nevertheless created a foundation for new relations between the main suppliers and the oil companies. Both oil companies and suppliers were eager to show they had common interests in future development projects - not least when it came to projects in new areas such as Azerbajdjan, Angola and Nigeria.

The internationalisation strategy of the Norwegian petroleum industry marks a new era. The first step in this direction was the BP -Statoil Alliance in 1990, which focused on exploration and production in the former Soviet-Union, Angola, Nigeria, Vietnam and China. The Alliance was not very successful and was dissolved in 1999. However, Statoil further intensified their efforts of establishing themselves on the international arena when they bought the Irish oil company Aran in 1995 seeking to grow in order to compete on the global arena. Hydro Oil \& Gas chose the same strategy and joined Statoil when they in 2006 tried to gain access to oil fields in Venezuela and capture a large share in the Russian field, Stochman. Both offensives failed. Nevertheless, in 2007 Statoil and Hydro Oil \& Gas merged and announced their intention to become big enough to compete on the international arena and 
thereby expand the Norwegian Petroleum Innovation System abroad. Indeed, the very term, "the Norwegian Petroleum Innovation System," may no longer be accurate, since the major producing companies and the main supplier in Norway, Aker Kvaerner, now seek to operate on a global scale (Ryggvik \& Engen 2005).

The establishment in 2007 of StatoilHydro indicates that the oil companies, major suppliers and public officials have succeeded in entering the international energy industry. The Norwegian government has to a larger extent than previously taken on the role of agent and advocate for efficiency and internationalising. The oil companies and main suppliers compare their performance against international energy firms, and Norwegian politicians and administrative representatives appear to have accepted the premise that Norwegian petroleum competence is an export item that must be competitive on international markets. Norway's future petroleum industry thus may seek greater autonomy from the political system that gave birth to it and the Norwegian Petroleum Innovation System.

\section{Final remarks}

The characteristics of the Norwegian Petroleum Innovation System were on the one hand the increasing ability to solve bottlenecks connected to production and operation on the Norwegian shelf, and on the other a gradual learning process that supported expanded Norwegian participation in the petroleum business. While the initial phase of the petroleum development of Norway in the sixties was characterised by an absorptive capacity that was limited to receiving new technology, the building of Norwegian competence in the seventies and eighties was shaped by public policies that sought to expand Norwegian participation in technology development and supply as well as production. In this phase, the development of Norwegian organisations and ambitions for public control were important. This strategy also 
sought to use the growing oil sector as an instrument both for job creation and economic policy. Accordingly, the international oil industry represented a general challenge for the existing Norwegian industrial structure, while it also played the role of teacher and transmitter of new technology. New organisational routines were implemented and extended into the Norwegian industrial environment.

With the construction and execution of the Condeep design it became possible to speak of an independent Norwegian petroleum industry. The development of Statoil, Hydro and the main supplier industry signified that petroleum activity in Norway was entering a new phase. Large resources were also used in education and research. Publicly funded petroleum education and research were introduced at several levels within the R\&D System of Norway. In the last phases we may say that the adjustment was concluded, as the absorptive capacity that existed in the initial phases had supported the development of a "participant competence" or what we have denoted as the Norwegian Petroleum Innovation System.

Over time, arguments for Norwegian jobs also carried less weight with public officials as oil companies placed greater emphasis on profit criteria. With the emergence of a constellation of factors - the projected total resource foundation did not grow, newly discovered fields were generally smaller, and the price level sank - it became legitimate to search for completely new technologies that were both cheaper and less labour intensive. In the nineties it was organisational routines created by the Norwegian way of developing fields and only to a lesser degree lack of alternative technologies that prevented further development of the continental shelves. Due to new cost efficient technologies introduced in the nineties, we may say that the adjustment was concluded by the beginning of $21^{\text {st }}$ century. The Norwegian oil and gas actors perceived themselves ready to fully participate in the international system of energy producers. 


\section{Notes}

${ }^{1}$ The history of the first oil concession laws is treated in detail in Norsk Oljehistorie (The Norwegian Oil History Vol 1) by Tore Joergen Hanisch and Gunnar Nerheim.

${ }^{2}$ In 1958, a year of economic stagnation in Norway, a commission was appointed to examine the conditions favourable for foreign investment in Norway. The Commission's foreman was Trygve Lie, former Secretary General in the United Nations. It was Lie that the oil companies first approached regarding access to what was to become the Norwegian sector. See also Hanisch \& Nerheim 1993.

${ }^{3}$ In Stavanger, Haugesund, Stord and Verdal, small cities/rural areas along the western coast of Norway, shipyards became important contractors to the oil industry

${ }^{4}$ At this point of time, however, Rosenberg shipyard had not considered oil rigs and long into the 1970's it continued to give priority to the construction of gas tankers.

${ }^{5}$ One explanation is that a large part of the shares at this time were in foreign hands. The authorities possibly felt that this situation was too risky to invest capital which in any case would be controlled by foreigners. It was better, therefore, to rely solely on foreign companies. The repurchase of Hydro shares by the Borten government in 1970 meant that the state acquired $51 \%$ of the company.

${ }^{6}$ It should be noted that Hydro and the former Norwegian oil company Saga also benefited from the "Norwegianisation policy", but in a much less dominating way than Statoil. Both of the former had to stand at the end of the queue during this period. See Ryggvik 2000.

${ }^{7}$ In connection with the fourth concession round in 1978, foreign companies were called on to co-operate with Norwegian industry in research and development. That was the beginning of the so-called technology agreement. The introduction of the technology agreement should be seen in the context of the desire for Norwegianisation and for developing an active Norwegian participation in petroleum activities (Blichner, 1995).

${ }^{8}$ Grønhaug, Lensberg \& Reve, 1993. However, this study gives greater significance to the state's intervening role than Michael Porter himself does in "The Competitive Advantages" (Porter 1995).

9 When Mobil argued for a strategy that suited Norwegian interests, Statoil voted consistently with Mobil against the other companies in the concession group.

${ }^{10}$ Organising in the form of module construction was important here. Under pressure from Statoil and the Norwegian government, a letter of intent was signed which ensured that this building principle would be carried out consistently on Statfjord B and C. On Statfjord A, Aker argued against Mobil that it would be wise to build a large number of modules on the platform itself, something that increased the Aker group's portion of the supply business appreciably. That fitted in well with Statoil's overall strategy.

${ }^{11}$ It was claimed that the large cost overruns of the seventies and the criticisms which followed resulted in the oil companies improving their management system for developing fields, and in up-scaling the cost estimates in their budgets rather than changing technology. Thus the final investment costs looked much more acceptable in comparison with the original budgets.

${ }^{12}$ White paper no. 24 (1983-84).

${ }^{13}$ White paper no. 35 (1984-85). Parliament decided in 1984 on a new organisational form for its direct economic engagement SDFI (in Norwegian, SDØE - statens direkte økonomiske engasjement). This principle implied, among other things, that part of the income, taxes, and investment that previously had been transferred 
to Statoil would now be channelled directly to Statoil.

${ }^{14}$ White paper no. $40(1982-83)$.

${ }^{15}$ White Paper no. 35 (1984-85). This report was based entirely on the conclusions from NOU (Norwegian Public Report) Norsk Offentlig Utredning, 1983. The Tempo committee).

${ }^{16}$ These assignments came outside the fourth concession round and were reserved for Norwegian companies. This must be seen in connection with the State's Norwegianisation policy. 


\section{References}

Andersen, Haakon With (1986) Fra det britiske til det amerikanske produksjonsideal. Forandringer i teknologi og arbeid ved Aker. Mek. Verksted og i norsk skipsbyggingsindustri 1935-1970 (From the British to the American Production ideal. Changes in Technology and Work in Aker and in the Norwegian shipbuilding Industry 1935-1970). Trondheim.

Andersen, Svein S. (1993) The Struggle over the North Sea. Governmental Strategies in Denmark, Britain and Norway. Scandinavia University Press: Oslo

Blichner, Lars Christian (1995) Radical Change and Experimental Learning. LOSrapport 9511: Bergen .

Cohen \& Levinthal (1990) Absorptive Capacity. Administrative Quarterly Journal.

Engeland, Sveinung (1995) Ingeniørfrabrikk på norsk. Oppbygginga av norsk petroleumsrelatert engineeringkompetanse. Hovedoppgave i Historie. Universitetet i Oslo: Oslo

Engen, Ole Andreas (1997) En evne til å ta imot in Sejersted, Francis \& Olsen, Odd Einar (red.) Oljevirksomheten som teknologiutviklingsprosjekt. Oslo: Ad Notam.

Engen, Ole Andreas (1997) Rhetoric and Realities. The NORSOK programme and Technical and Organisational Change in The Norwegian Petroleum Industrial Complex. Dissertation submitted for the degree of dr. polit. University of Bergen: Bergen

Engen, Ole Andreas \& Olsen, Odd Einar. (1997) “ Et teknologisk system i endring - fra norsk stil til internasjonale ambisjoner” i Olsen \& Sejersted (red). Oljen som teknologiutviklingsprosjekt, adNotam Gyldendal: Oslo

Gjelsvik, Martin, Hatenaki, Sachi, Lester, Richard \& Westnes Petter (2006) From Black Gold to Human Gold. MiT -IPC-IRIS: Stavanger

Grønhaug, Kjell, Reve, Torgeir, Lensberg, Terje (2006) Et konkurransedyktig Norge. Tano: Oslo

Gulbrandsen, Magnus \& Nerdrum, Lars (2007) Public Sector Research and Industrial Innovation in Norway - A Historical Perspective. TIK working papers on Innovation Studies. University of Oslo: Oslo

Hahn Pedersen, Morten (1997) Ap Moeller og den Danske Olie (AP Moeller and the Danish Oil), Schultz. Denmark. 
Hanisch, Tore Jørgen \& Nerheim, Gunnar (1993) Norsk Oljehistorie Bind I, Leseforlaget: Oslo

Hodgson, Geoffrey M. (1988) Economic and Institutions, Polity Press: London

Kristiansen, Trond Schrader (1997) Teknologiske valg under utbyggingen av Osebergfeltet. Hovedoppgave i Historie, Universitetet i Oslo: Oslo

Moen, Svein Erik (2007) Innovation and production in the Norwegian aluminium industry. TIK working papers on Innovation Studies. University of Oslo: Oslo

Nelson, Richard (ed.) (1993) National Innovation Systems. A Comparative Analysis. Oxford University Press: New York/Oxford.

Nerheim, Gunnar (1996) Norsk oljehistorie (Bind II) - En gassnasjon blir til. Leseforlaget: Oslo

North, Douglass (1991) Institutions, Institutional Change and Economic Performace. Cambridge Univerisity Press: Cambridge

Olsen, Johan P (1989) Petroleum og Politikk. Tano: Oslo.

Olsen, Odd Einar \& Engen; Ole Andreas (1997) “Konservativ nyskaping i offshore oljeproduksjon - Olsen \& Sejersted. Oljen som teknologiutviklingsprosjekt. AdNotam Gyldendal: Oslo.

Porter, Michael (1985) The Competitive Advantage, Free Press: New York

Rommetvedt, Hilmar (1991) Statoils rolle. RF - Rogaland Research.24/91: Stavanger

Ryggvik, Helge (2005) Norsk Oljevirksomhet mellom det nasjonale og det internasjonale. En studie av selskapsstruktur og internasjonalisering. Dr. gradsavhandling i Historie. University of Oslo. Oslo

Ryggvik, Helge \& Engen, Ole Andreas (2005) Den skjulte dagsorden. Rammer for en alternativ oljepolitikk. SAFE - rapport: Stavanger

Sejersted, Francis (1993) Demokratisk Kapitalisme. Universitetsforlaget: Oslo

Sejersted, Francis (1999) Systemtvang eller politikk. Universitetsforlaget: Oslo

Sogner, Knut (2007) Slow Growth and Evolutionary Change. The Norwegian ITIndustry enters the Global Age, 1970-2005. TIK working papers on Innovation Studies. University of Oslo: Oslo 
Thomsen, Egil (1991) Vedtaket om å bygge ut Gullfaks fase II. En beslutningsteoretisk analyse av forholdet mellom Statoil og Storting, regjering og Olje - og Energidepartementet. Hovedoppgave i Statsvitenskap, Universitetet i Oslo: Oslo

Wicken, Olav (2007) The Layers of National Innovation Systems: The Historical Evolution of a National Innovation System in Norway. TIK working papers on Innovation Studies. University of Oslo: Oslo 
Figure 1: The Norwegian Oil and Gas Industry share of GNP (Source: Statistics Norway)

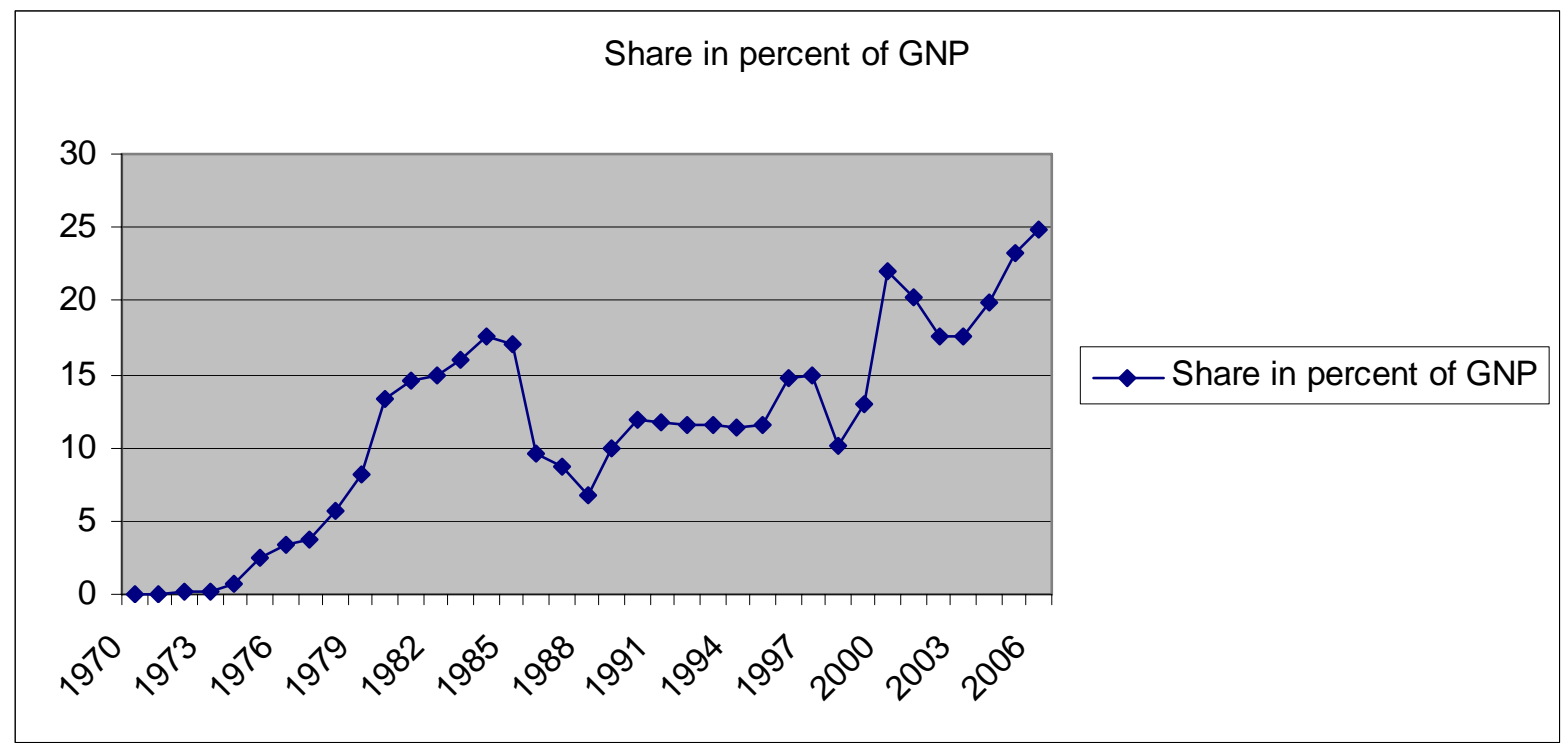

Figure 2: Rate of employment 1973-2002 (Source: Statistics Norway)

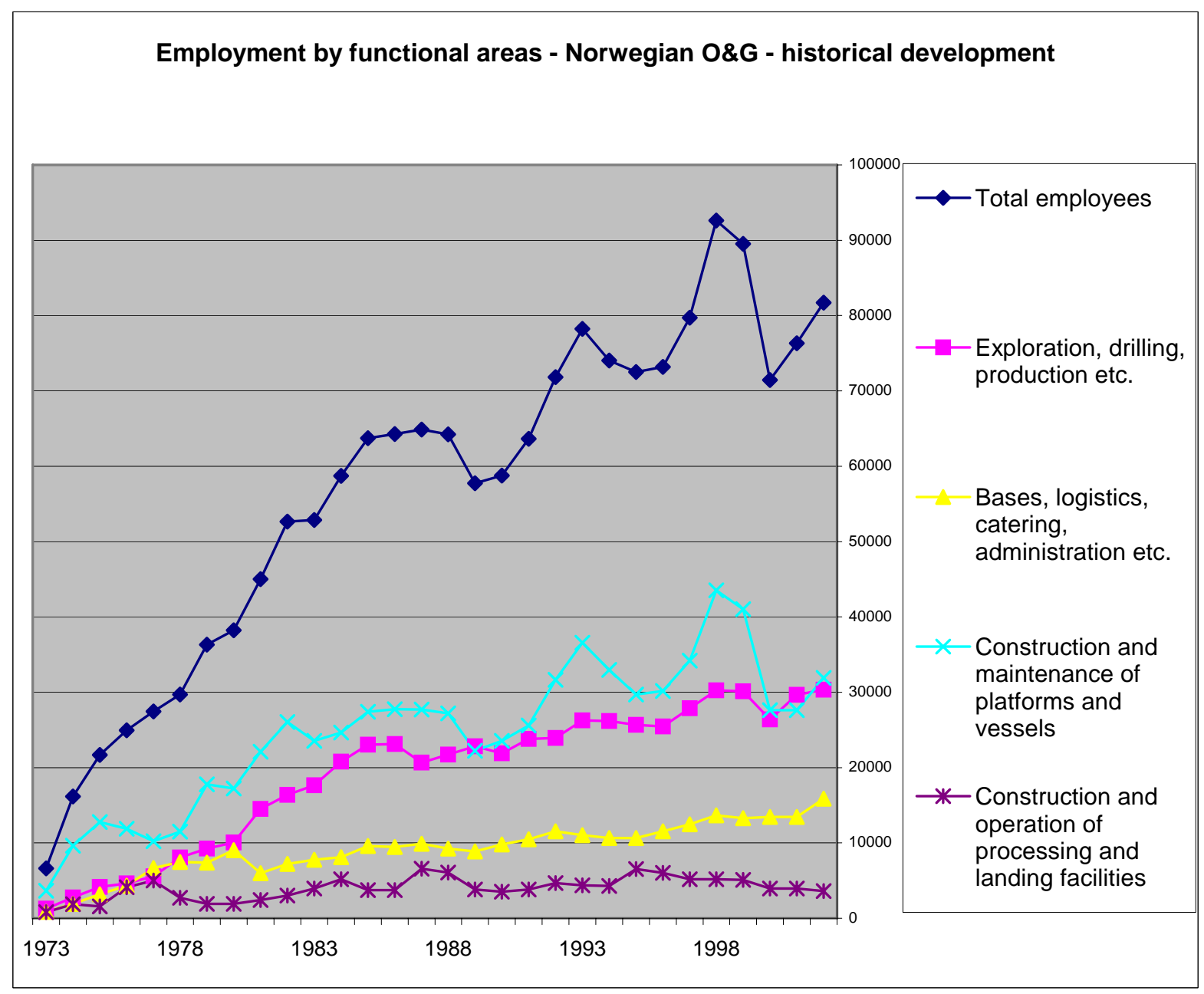


Figure 3: The Ekofisk field (Source: the Norwegian Oil Museum)

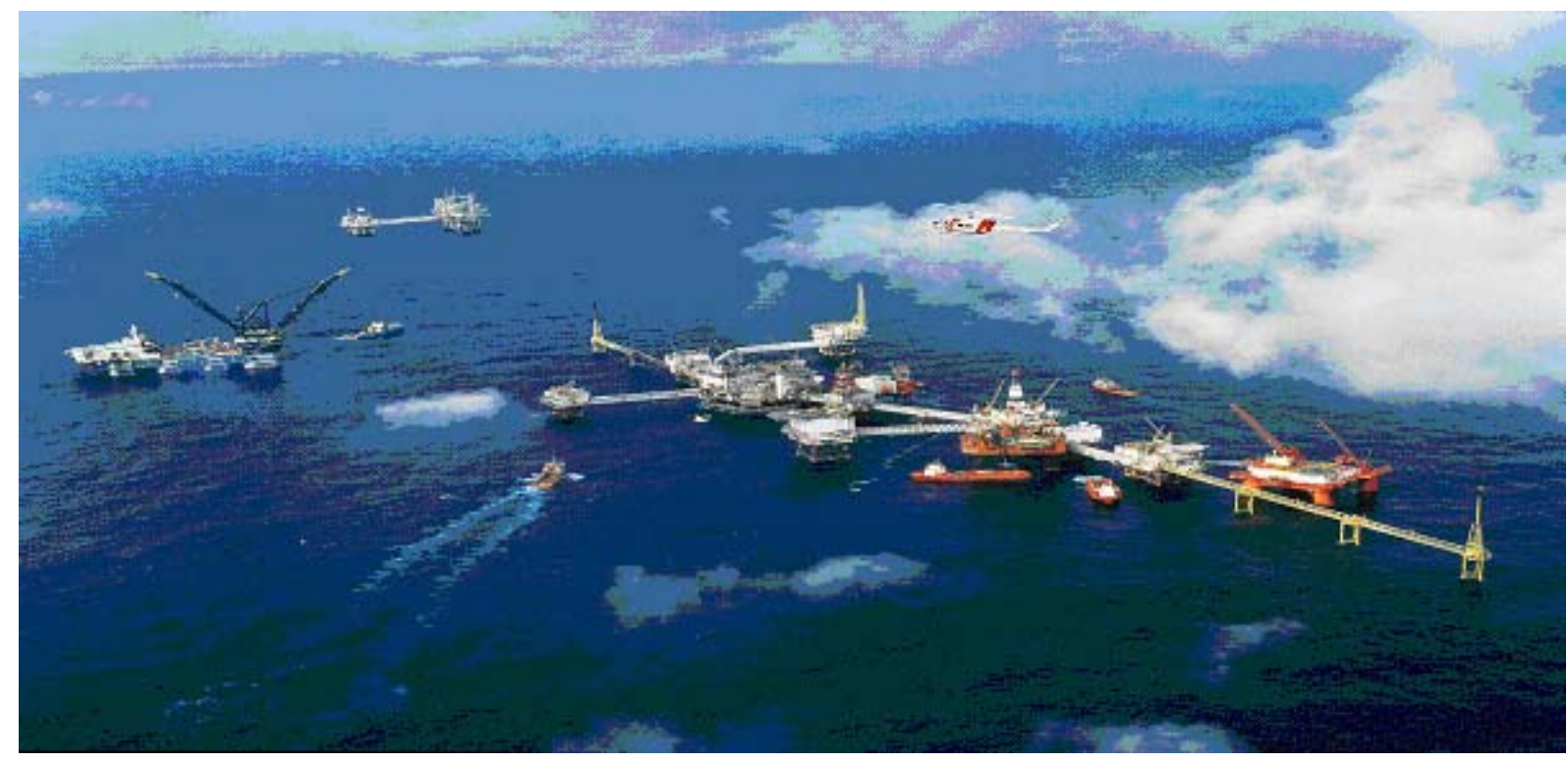

Figure 4: The largest Condeep ever built. The tow of the Troll A plattform 1999 (Source: the Norwegian Oil museum)

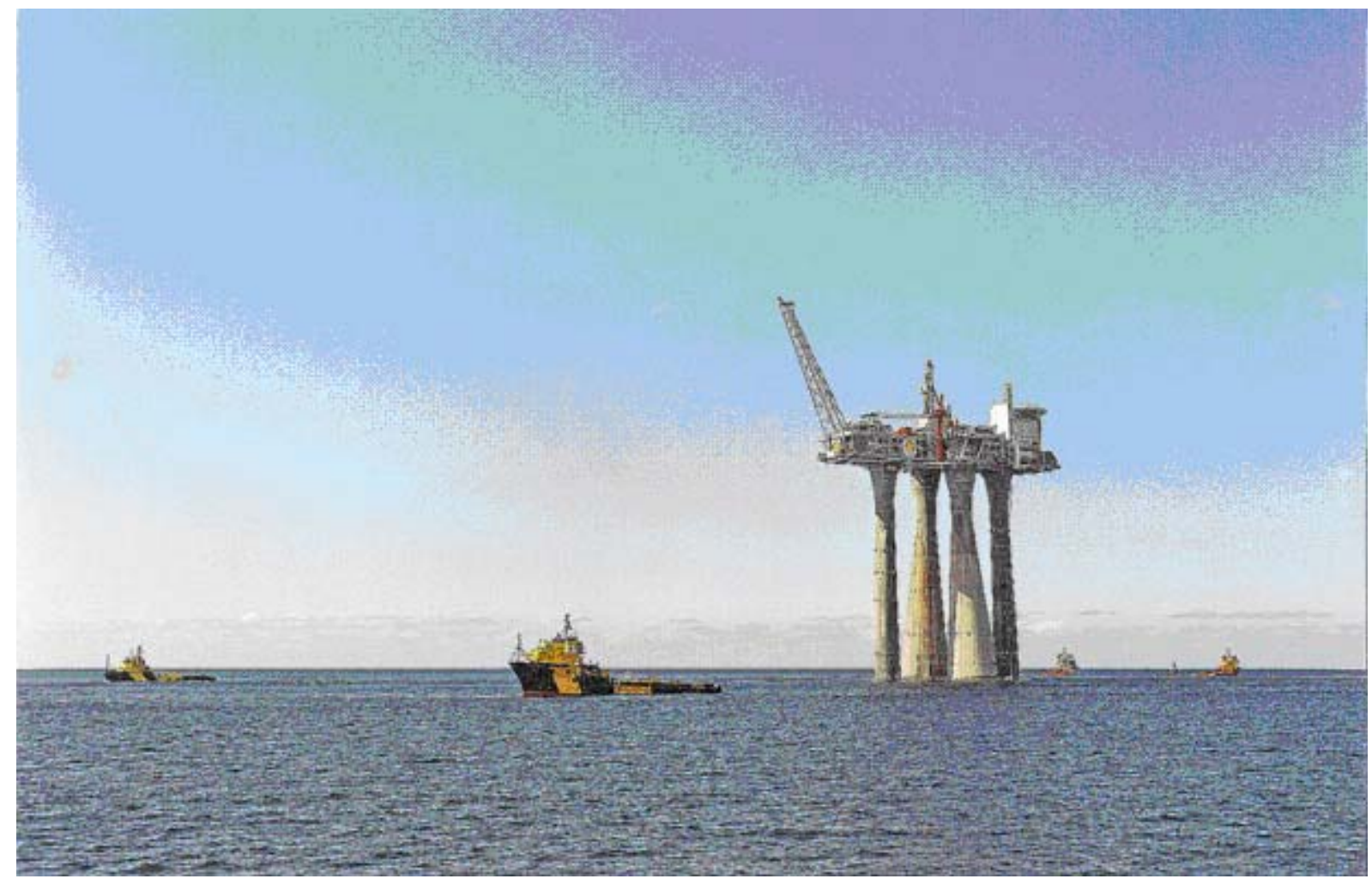


Figure 5: Public R\&D expenditures in the Norwegian National Budget 1985-2004.

Oil \& Gas exploration and production. Current prices. (Source: Statistics Norway)

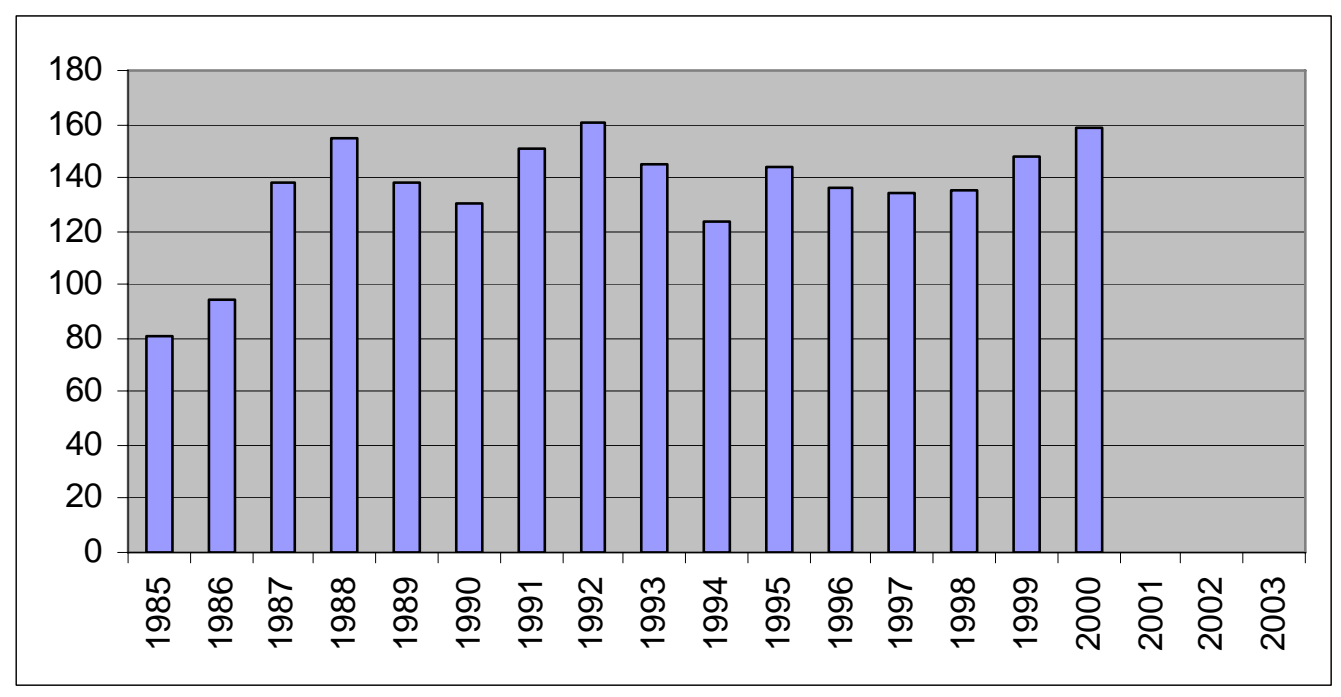

Figure 6: Illustration of the new technological regime. Subsea installations connected to the Frigg Field. (Source: the Norwegian Oil Museum)

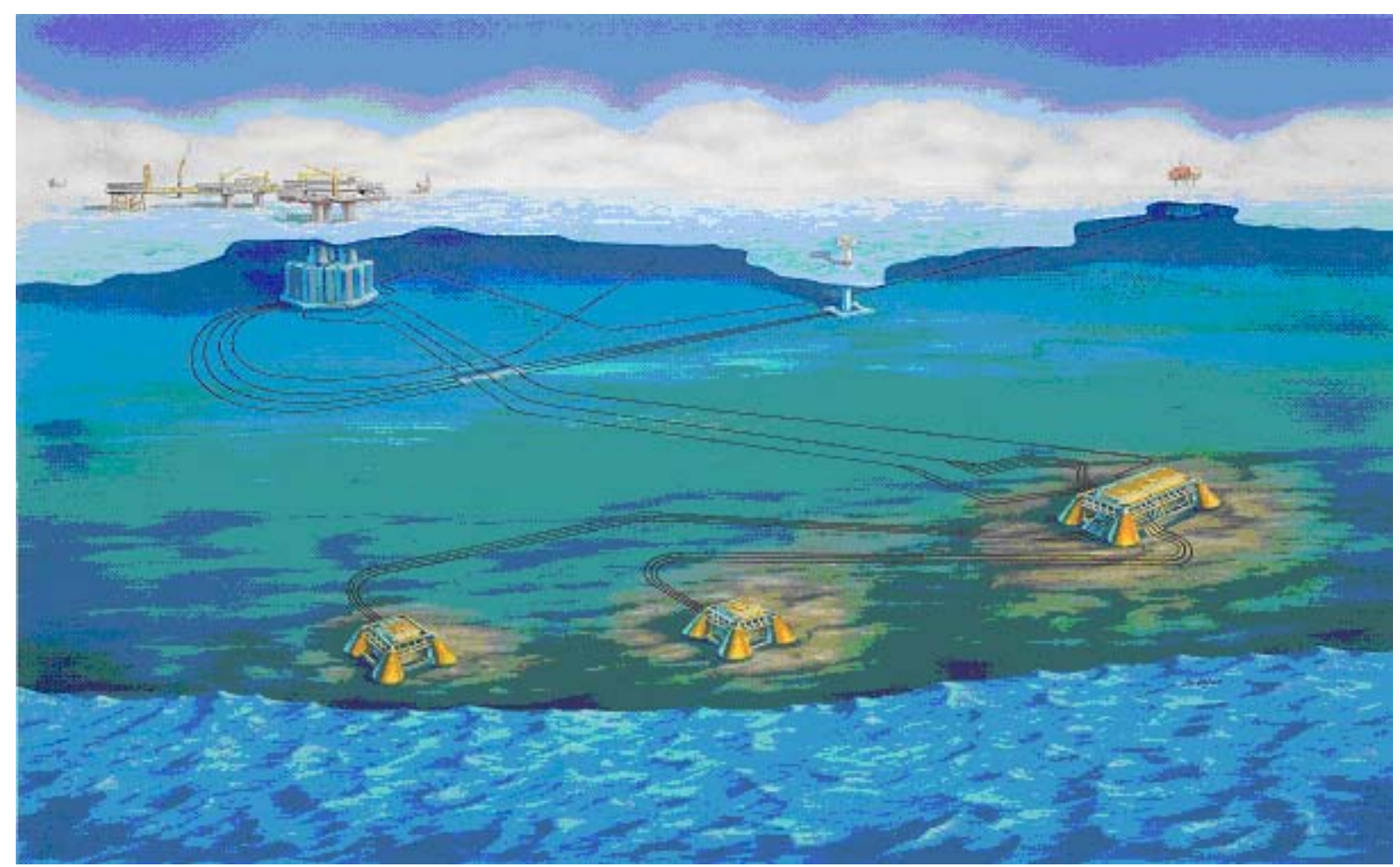




\section{Box 1: Ekofisk}

The Ekofisk Area is located southwest of Stavanger, in the southern part of the North Sea. Two export pipelines run from the Ekofisk Complex. Through these the oil and gas is transported to terminals in Teesside, England and Emden, Germany.

\section{Box 2: The Condeeps}

Condeep (abbr. concrete deep water structure) refers to a type of gravity base structure for oil platforms. A Condeep usually consists of a base of concrete oil storage tanks from which one, three or four concrete shafts rise.The original Condeep always rests on the sea floor, and the shafts rise to about 30 meters above the sea level. The platform deck itself is not a part of the construction. Following the success of the concrete oil storage tank on the Ekofisk field, Norwegian Contractors introduced the Condeep production platform concept in 1973. This gravity base structure for platform was unique in that it was built from reinforced concrete instead of steel, which was the norm up to that point. The platform was made for the heavy weather conditions and the great water depths found in the North Sea. In addition to their use on the Norwegian Shelf, there are three condeeps on the UK shelf, Beryl A, B and Brent A. Condeeps are used nowhere else. The picture shows the last and biggest condeep ever built. The Troll platform was towed over $200 \mathrm{~km}$ from Vats in the northern part of Rogaland to the Troll field 80 km north-west of Bergen. Troll A has an overall height of 472 meters and weighs 656,000 tons and has the distinction of being the tallest structure ever moved by mankind.

\section{Box 3: Industrial spinoffs of the Norwegian oil and Gas industry}

An important issue that unfortunately cannot be elaborated thoroughly in this paper concerns the industrial spin offs of the Norwegian Petroleum Innovation System. During the last ten years this issue has been discussed in several occasions among the key actors, but the issue has attracted surprisingly little political attention. At least two important sectors have benefited from the development of Norway's oil industry. The breakthrough of under water system and advanced methods for seismic surveillance gave new opportunities for petroleum-oriented IT companies i.g Simrad, Kongsberg Offshore System (Sogner 2007). A second major industrial beneficiary of Norway's oil and gas industry has relied on the development of LNG technology (Liquid Natural Gas), which has sparked demand for advanced ship designs and processing equipment. The LNG technology (Ships and terminals) has increased its significance during the last years. Aker Kvaerner is an important actor in the LNG market and MARINTEK in Trondhjem has become one the major R\&D suppliers to the Norwegian LNG producers. The Snøhvit project involves bringing huge volumes of natural gas to land for liquefaction and export from the first plant of its kind in Europe and the world's northernmost liquefied natural gas facility. Arctic LNG supplies from Snøhvit provide new opportunities for Statoil in the US gas market. 